\title{
Pharmacodynamics of Practolol in Chronic Renal Failure
}

\author{
J. B. EASTWOOD, J. R. CURTIS, R. B. SMITH
}

British Medical fournal, 1973, 4, 320-322

\section{Summary}

Plasma levels of practolol were measured in advanced chronic renal failure. The plasma half life was found to be markedly prolonged. During haemodialysis considerable shortening of the half life occurred. Therapeutic blood levels of practolol can be achieved in maintenance haemodialysis patients by the administration of $200 \mathrm{mg}$ of the drug by mouth at the beginning and end of each dialysis.

\section{Introduction}

Practolol, 4-(2-hydroxy-3-isopropylaminopropoxy) acetanilide (Eraldin), is a cardioselective beta-blocking agent shown to be effective in the management of a variety of cardiac arrhythmias. It has the advantage over other beta-blocking agents that it produces negligible adrenergic beta-blockade of vascular and respiratory smooth muscle (MacDonald and McNeill, 1968). The plasma half life in normal subjects has been shown to be $10 \pm 2$ hours (Fitzgerald and Scales, 1968).

Cardiac arrhythmias are common in patients with severe renal failure and particularly in those undergoing acute or chronic \footnotetext{
Department of Medicine, Charing Cross Hospital Medical School,
London W.6

J. B. EASTWOOD, M.B., M.R.C.P., Lecturer in Medicine

J. R. CURTIS, M.D., F.R.C.P., Consultant Nephrologist and Senior Lecturer in Medicine.

Imperial Chemical Industries Limited, Macclesfield, Cheshire R. B. SMITH, B.SC., M.D., Medical Adviser.
}

haemodialysis. As practolol is largely excreted unchanged in the urine one would expect accumulation of the drug if normal doses were given in the presence of renal failure. It was therefore thought important to measure blood levels and determine the plasma half life of the drug in patients with chronic renal failure, and to know whether blood levels and plasma half life were influenced by haemodialysis.

\section{Methods}

Eighteen patients with chronic renal failure were studied (table I). Thirteen of these had terminal renal failure and were being treated by maintenance haemodialysis. Of these 13 patients seven were anephric. Dialysis was carried out for a total of 28 to 32 hours a week with modified Kiil dialysers with cuprophane membranes (PT 150). A single dose of practolol was given to each subject, nine patients receiving $100 \mathrm{mg}$ and four receiving $200 \mathrm{mg}$. The remaining five patients were suffering from advanced renal failure (glomerular filtration rate $<20 \mathrm{ml} / \mathrm{min}$ ) and were not on maintenance haemodialysis. All five received the $200 \mathrm{mg}$ oral dose. A $4 \mathrm{ml}$ sample of blood was taken into oxalate tubes at intervals up to 90 hours after the dose, and the samples were stored in a refrigerator $\left(4^{\circ} \mathrm{C}\right)$ until analysed. In two of the dialysis patients aliquots of urine were collected into edetic acid tubes for the three days after the dose of practolol, The samples being kept at $4^{\circ} \mathrm{C}$ until analysed.

Eight of the 13 dialysis patients were also studied during a 14-hour haemodialysis from three to 74 hours after an oral dose of practolol (table II). In four of these patients a $200 \mathrm{mg}$ dose was given and in the other four a $100 \mathrm{mg}$ dose was given. Blood was taken into oxalate tubes at intervals during the 14-hour haemodialysis.

Glomerular filtration rate in the five non-dialysed subjects was estimated by a single-shot technique using ${ }^{51} \mathrm{Cr}$-edetic acid (Chantler et al., 1969). The practolol content of both blood and urine samples was measured colorimetrically (Fitzgerald and

TABLE I-Plasma Level and Half-life of Practolol in Chronic Renal Failure

\begin{tabular}{|c|c|c|c|c|c|c|c|c|c|c|c|c|c|c|c|c|c|c|c|c|c|}
\hline \multirow{2}{*}{$\begin{array}{l}\text { Practolol } \\
\text { Dose }\end{array}$} & \multirow{2}{*}{$\begin{array}{l}\text { Case } \\
\text { No. }\end{array}$} & \multirow[t]{2}{*}{ Age } & \multirow[t]{2}{*}{ Sex } & \multirow{2}{*}{$\underset{(\mathrm{ml} / \mathrm{min})}{\text { G.F.R. }}$} & \multicolumn{16}{|c|}{$\begin{array}{l}\text { Plasma Practolol in } \mu \mathrm{g} / \mathrm{ml} \\
\text { (Hours after Dose) }\end{array}$} & \multirow{2}{*}{$\begin{array}{l}\text { Plasma } \\
\text { Half Life } \\
\text { (Hours) }\end{array}$} \\
\hline & & & & & 1 & $1 \frac{1}{2}$ & 3 & 4 & 6 & 10 & 12 & 24 & 36 & 44 & 48 & 56 & 60 & 72 & 80 & 90 & \\
\hline $100 \mathrm{mg}$ & 1 & 29 & F. & $<3$ & - & - & 1.5 & 1.25 & $1 \cdot 15$ & - & 1.05 & 0.85 & $\begin{array}{c}0.73 \\
(30.5)\end{array}$ & - & 0.73 & - & 0.55 & 0.60 & 0.60 & - & 61 \\
\hline$"$ & 2 & $\begin{array}{l}54 \\
25\end{array}$ & $\begin{array}{l}\text { M. } \\
\text { F. }\end{array}$ & $<3$ & 二 & 二 & $1 \cdot 0$ & 0.9 & $\stackrel{0.9}{-}$ & $\overline{1.9}$ & $\begin{array}{l}0.75 \\
1.6 \\
(20)\end{array}$ & $\begin{array}{l}0.80 \\
1.6\end{array}$ & $\begin{array}{l}0.85 \\
1.5\end{array}$ & $0 . \overline{9}$ & $\begin{array}{l}0.70 \\
1.4\end{array}$ & $\overline{-}$ & $\stackrel{0.55}{-}$ & $\stackrel{0.55}{-}$ & 二 & 二 & $\begin{array}{l}93 \\
52\end{array}$ \\
\hline " & 4 & 60 & M. & $<3$ & - & - & - & - & 0.6 & - & - & - & $\begin{array}{l}0.5 \\
(32 \cdot 5)\end{array}$ & - & 0.5 & - & - & - & - & - & 147 \\
\hline $\begin{array}{l}\text { "' } \\
\text { "' } \\
\text { " }\end{array}$ & $\begin{array}{l}5^{*} \\
6 \\
7 \\
8^{*} \\
9\end{array}$ & $\begin{array}{l}49 \\
47 \\
51 \\
54 \\
57\end{array}$ & $\begin{array}{l}\text { F. } \\
\text { F. } \\
\text { M. } \\
\text { M. } \\
\text { M. }\end{array}$ & $\begin{array}{l}<3 \\
<3 \\
<3 \\
<3 \\
<3\end{array}$ & $\begin{array}{l}\bar{Z} \\
\bar{Z} \\
0.69 \\
0.65\end{array}$ & $\begin{array}{l}\bar{Z} \\
0.66 \\
0.41 \\
0.68\end{array}$ & $\begin{array}{l}\bar{z} \\
\bar{z}\end{array}$ & $\begin{array}{l}0.76 \\
0.75 \\
1.24 \\
1.08\end{array}$ & $\begin{array}{c}0 . \overline{76} \\
0.64 \\
1.19 \\
0.65\end{array}$ & $\begin{array}{l}\bar{二} \\
\overline{1.05} \\
0.54\end{array}$ & $\begin{array}{l}0.8 \\
0.76 \\
0.66 \\
0.97 \\
0.57\end{array}$ & $\begin{array}{l}0.9 \\
0.66 \\
0.55 \\
0.86 \\
0.54\end{array}$ & $\begin{array}{c}0.6 \\
0.59 \\
0.48 \\
= \\
-\end{array}$ & $\begin{array}{l}\bar{z} \\
\bar{z}\end{array}$ & $\begin{array}{l}0.5 \\
0.59 \\
0.45 \\
= \\
-\end{array}$ & $\begin{array}{l}= \\
\bar{z}\end{array}$ & $\begin{array}{l}0.5 \\
0.49 \\
0.31 \\
= \\
=\end{array}$ & $\begin{array}{l}0.5 \\
0.48 \\
0.30 \\
=\end{array}$ & $\begin{array}{l}\bar{z} \\
\bar{z}\end{array}$ & $\bar{z}$ & $\begin{array}{l}61 \\
94 \\
51 \\
40 \\
30.5\end{array}$ \\
\hline $200 \mathrm{mg}$ & $10^{*}$ & 45 & M. & $<3$ & - & - & - & - & 一 & $2 \cdot 7$ & $\begin{array}{l}2 \cdot 4 \\
(20)\end{array}$ & $2 \cdot 3$ & - & - & - & - & - & 一 & - & - & 64 \\
\hline " & $11^{*}$ & 26 & M. & $<3$ & - & 一 & - & 一 & - & $\begin{array}{l}2 \cdot 0 \\
(8 \cdot 5)\end{array}$ & - & $1 \cdot 8$ & $\begin{array}{l}1 \cdot 3 \\
(32 \cdot 5)\end{array}$ & - & $1 \cdot 4$ & $1 \cdot 3$ & - & - & - & - & 84 \\
\hline$"$ & $\begin{array}{l}12^{*} \\
13^{*}\end{array}$ & $\begin{array}{l}28 \\
25\end{array}$ & $\begin{array}{l}\mathbf{F} . \\
\mathbf{F} .\end{array}$ & $\begin{array}{l}<3 \\
<3\end{array}$ & 二 & 二 & 二 & $\overline{-}$ & $1 \cdot 7$ & 二 & 二 & $\begin{array}{l}1 \cdot 3 \\
2 \cdot 6\end{array}$ & $\begin{array}{l}1 \cdot 3 \\
2 \cdot 3 \\
(32)\end{array}$ & 二 & $\begin{array}{l}1.5 \\
1.9\end{array}$ & $2 \cdot \overline{2}$ & $1 \cdot 4$ & $\begin{array}{l}1.1 \\
1.9\end{array}$ & $\begin{array}{l}\overline{1} \cdot 3 \\
(74)\end{array}$ & $=$ & $\begin{array}{r}166 \\
73\end{array}$ \\
\hline$"$ & 14 & 50 & M. & $5 \cdot 6$ & - & - & 一 & - & - & 一 & - & $\begin{array}{l}3.7 \\
(19)\end{array}$ & $\begin{array}{l}2 \cdot 4 \\
(31)\end{array}$ & $\begin{array}{l}1.9 \\
(40)\end{array}$ & - & $1 \cdot 3$ & $\begin{array}{l}1.2 \\
(65)\end{array}$ & - & - & 0.8 & $32 \cdot 5$ \\
\hline " & 15 & 20 & F. & $5 \cdot 6$ & - & - & 一 & - & $2 \cdot 1$ & - & $\begin{array}{l}2 \cdot 4 \\
(16 \cdot 5)\end{array}$ & $2 \cdot 5$ & $\begin{array}{l}1.5 \\
(32)\end{array}$ & $\begin{array}{l}1 \cdot 3 \\
(41)\end{array}$ & $1 \cdot 4$ & - & - & - & - & - & 30 \\
\hline " & 16 & 50 & F. & $5 \cdot 7$ & - & - & - & - & - & - & - & $1 \cdot 1$ & - & $1 \cdot 2$ & - & $\begin{array}{l}1 \cdot 2 \\
(51 \cdot 5)\end{array}$ & - & 0.6 & 0.6 & 0.6 & $55 \cdot 5$ \\
\hline$"$ & 17 & 82 & F. & 10.5 & - & - & - & - & - & - & - & $2 \cdot 0$ & - & $1 \cdot 2$ & - & $\begin{array}{l}0.5 \\
(52)\end{array}$ & 0.3 & - & - & - & $15 \cdot 0$ \\
\hline " & 18 & 27 & M. & $16 \cdot 8$ & - & - & - & - & - & - & - & $\mid \begin{array}{l}1 \cdot 2 \\
(21 \cdot 5)\end{array}$ & $\begin{array}{l}0.9 \\
(31)\end{array}$ & - & 0.7 & 0.6 & - & 0.5 & 0.3 & $0 \cdot 2$ & 29 \\
\hline
\end{tabular}


TABLE II-Effect of Haemodialysis on Plasma Level of Practolol

\begin{tabular}{|c|c|c|c|c|c|c|c|c|c|c|c|c|c|c|c|c|}
\hline \multicolumn{2}{|c|}{ Practolol } & \multirow{2}{*}{$\begin{array}{l}\text { Case } \\
\text { No. }\end{array}$} & \multirow{2}{*}{ Age } & \multirow{2}{*}{ Sex } & \multirow{2}{*}{$\begin{array}{l}\text { G.F.R. } \\
(\mathrm{ml} / \mathrm{min})\end{array}$} & \multicolumn{10}{|c|}{$\begin{array}{c}\text { Plasma Practolol in } \mu \mathrm{g} / \mathrm{ml} \\
\text { (Hours on Dialysis) }\end{array}$} & \multirow{2}{*}{$\begin{array}{c}\text { Plasma } \\
\text { Half Life } \\
\text { (Hours) }\end{array}$} \\
\hline Dose & $\begin{array}{l}\text { No. of Hours } \\
\text { before Start } \\
\text { of Dialysis }\end{array}$ & & & & & 0 & 1 & 2 & 3 & 4 & 5 & 7 & 8 & 10 & 14 & \\
\hline $\begin{array}{c}100 \mathrm{mg} \\
\text { ” } \\
\text { ” }\end{array}$ & $\begin{array}{r}48 \\
4 \\
3 \\
4\end{array}$ & $\begin{array}{l}3^{*} \\
7 \\
8^{*} \\
9\end{array}$ & $\begin{array}{l}25 \\
51 \\
54 \\
57\end{array}$ & $\begin{array}{l}\mathrm{F} . \\
\mathrm{M} . \\
\mathrm{M} . \\
\mathrm{M} .\end{array}$ & $\begin{array}{l}<3 \\
<3 \\
<3 \\
<3\end{array}$ & $\begin{array}{c}1.4 \\
1 \cdot 15 \\
0 \\
1 \cdot 21\end{array}$ & $\begin{array}{c}\overline{7} \\
0.95 \\
1.23\end{array}$ & 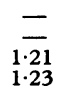 & $\frac{\overline{1}}{1 \cdot 15}$ & $\begin{array}{l}\overline{-} \\
0 \cdot 67 \\
1 \cdot 18\end{array}$ & $=$ & $\frac{\overline{0}}{\overline{-}}$ & $\begin{array}{l}\overline{-} \\
0.82 \\
0.74\end{array}$ & = & $\begin{array}{l}0.8 \\
0.65 \\
0.72 \\
0.69\end{array}$ & $\begin{array}{l}17.5 \\
17 \\
20.5 \\
14.5\end{array}$ \\
\hline $\begin{array}{c}200 \mathrm{mg} \\
\text { ", } \\
\text {, }\end{array}$ & $\begin{array}{l}25 \\
52 \\
74 \\
74\end{array}$ & $\begin{array}{l}10^{*} \\
11^{*} \\
12^{*} \\
13^{*}\end{array}$ & $\begin{array}{l}45 \\
26 \\
28 \\
25\end{array}$ & $\begin{array}{l}\text { M. } \\
\text { M. } \\
\text { F. } \\
\text { F. }\end{array}$ & $\begin{array}{l}<3 \\
<3 \\
<3 \\
<3\end{array}$ & $\begin{array}{l}2 \cdot 3 \\
1 \cdot 3 \\
1 \cdot 1 \\
1 \cdot 3\end{array}$ & $=$ & 二 & $=$ & $=$ & 二 & $\begin{array}{l}\bar{Z} \\
=\end{array}$ & E & 二 & $\begin{array}{l}1.3 \\
0.6 \\
0.8 \\
0.4\end{array}$ & $\begin{array}{l}17 \\
12 \cdot 5 \\
30 \\
8\end{array}$ \\
\hline
\end{tabular}

*Anephric.

Scales, 1968). The limit of sensitivity of this method at low blood levels is about $\pm 0 \cdot 1 \mu \mathrm{g} / \mathrm{ml}$. The samples in which the practolol content was low by this method were re-estimated by gas liquid chromatography. The half life of the drug in the plasma was calculated on a computer by the method of least squares.

\section{Results}

Details of the 13 maintenance haemodialysis patients (seven anephric; glomerular filtration rate $<3 \mathrm{ml} / \mathrm{min}$ in the other six) and plasma practolol levels at intervals after administration of the single oral dose are given in table $I$ and shown in fig. 1. These patients were studied in between dialyses.

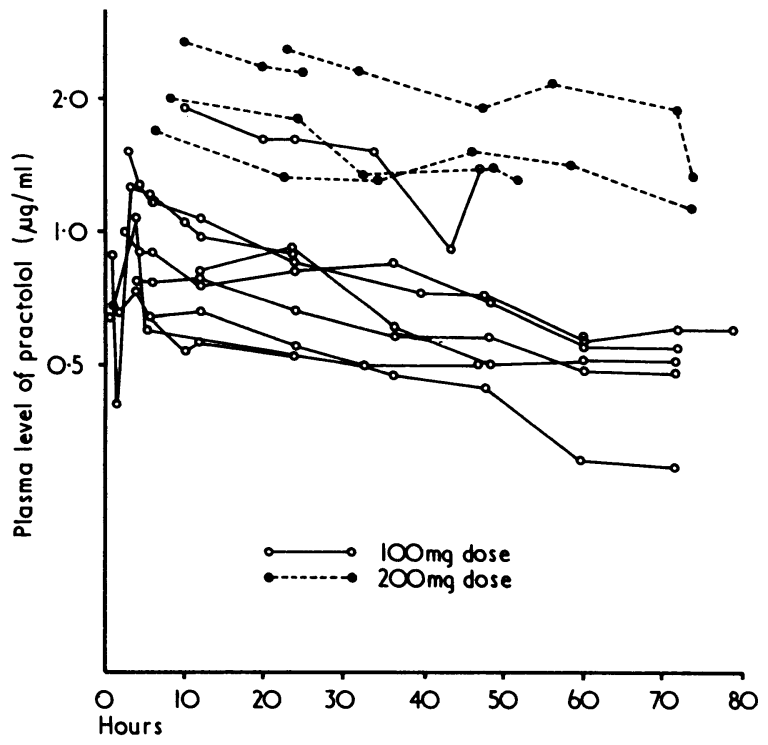

FIG. 1-Plasma levels of practolol in patients with terminal renal failure.

Blood levels within the therapeutic range of 1.5 to $2.4 \mu \mathrm{g} / \mathrm{ml}$ (Fitzgerald and Scales, 1968) were obtained in all four patients receiving the $200 \mathrm{mg}$ dose but in only two of the nine receiving $100 \mathrm{mg}$. In the seven in whom it was estimated measurable amounts of practolol were present in the plasma at 72 hours.

The plasma half life of practolol in these patients is given in table I and fig. 2. The mean half life was $78 \cdot 2 \mathrm{hr}$ (range 30.5$166 \mathrm{hr}$ ).

In the two patients in whom urine was collected for three days after the $100 \mathrm{mg}$ oral dose practolol could not be detected in any specimen.

Details of the five patients with chronic renal failure (glomerular filtration rate $5 \cdot 6-16 \cdot 8 \mathrm{ml} / \mathrm{min}$ ) and plasma practolol levels at intervals after administration of the single oral dose are given in table I. The plasma half life of practolol in these patients ranged from 15.0 to $55.5 \mathrm{hr}$ (table I, fig. 2).

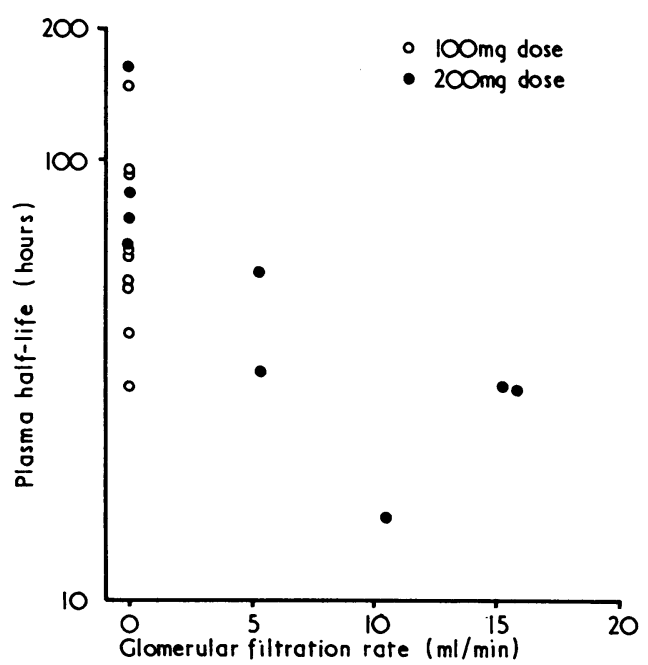

FIG. 2-Half life of practolol in various degrees of renal failure.

Though the number of patients studied was small it appears that there is an inverse relation between the plasma half life and the glomerular filtration rate.

Details of the eight maintenance haemodialysis patients studied during a single haemodialysis. (Six anephric; glomerular filtration rate $<3 \mathrm{ml} / \mathrm{min}$ the other two) and plasma practolol levels during dialysis are given in table II and plotted in fig. 3. The mean plasma half life in these patients was $17 \cdot 1 \mathrm{hr}$ (range 8-30 hr).

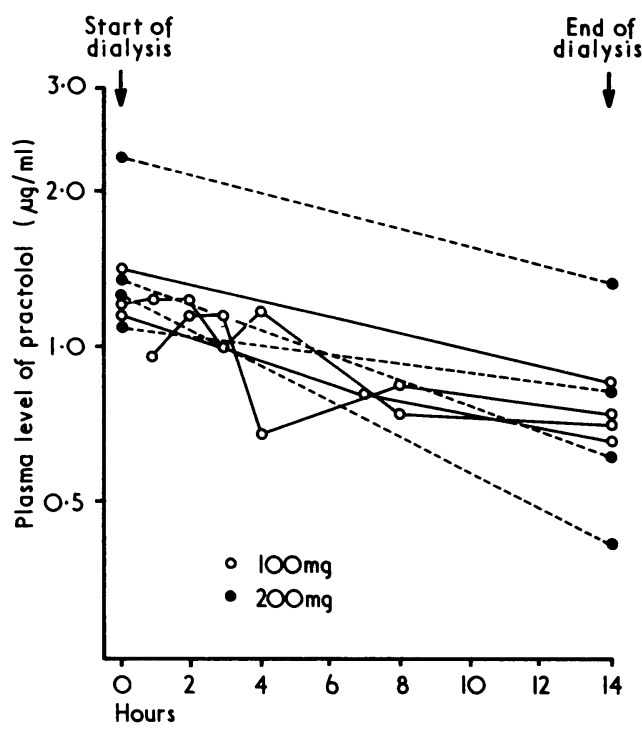

FIG. 3-Effect of haemodialysis on plasma levels of practolol. 


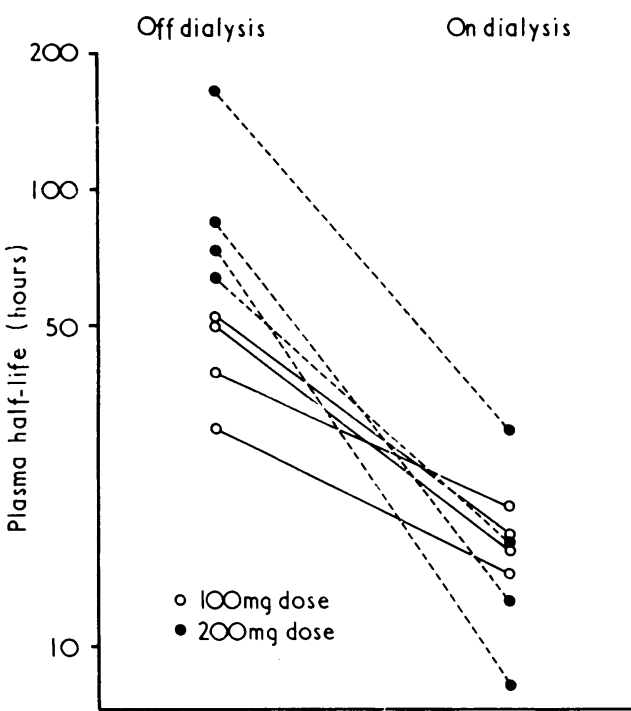

FIG. 4-Effect of haemodialysis on half life of practolol.

The plasma half life of these eight patients is compared in fig. 4 with the half life determined in the same patients when not on dialysis. The mean plasma half life for these patients when not on dialysis was $70 \mathrm{hr}$ (range $30 \cdot 5-166 \mathrm{hr}$ ). The difference between the means was significant (Wilcoxon matched pairs, signed ranks test; $P<0.005$ ).

No adverse effects were noted by any patient during this study.

\section{Discussion}

The results of this study show that the excretion of practolol is markedly impaired in advanced chronic renal failure. In those patients on maintenance haemodialysis, some of whom were anephric, the mean half life was 78.2 hours, compared with that for normal subjects of $10 \pm 2$ hours. In addition, practolol could not be detected in the urine of the two patients in whom it was examined. In those with a glomerular filtration rate of between 5 and $17 \mathrm{ml} / \mathrm{min}$ the half life was prolonged but not to the same degree as in those on maintenance haemodialysis, and was between 15 and 55.5 hours. From the limited data available it appears that the half life becomes significantly prolonged once the glomerular filtration rate falls below about $20 \mathrm{ml} / \mathrm{min}$.

Blood levels of practolol obtained both with the 100 and 200 mg doses were comparable with those obtained by Fitzgerald and Scales (1968) for normal subjects. No attempt was made in this study to determine whether the enterohepatic recirculation proposed for rats by Scales and Cosgrove (1970) occurs in man.

There was a dramatic reduction in the half life during haemodialysis in eight patients. The mean half life of these eight in between dialyses was 70 hours, whereas during haemodialysis the mean half life was $17 \cdot 1$ hours. Thus practolol is rapidly removed by haemodialysis. This presumably reflects both the low molecular weight (262) and the lack of protein binding in the plasma.

In the maintenance haemodialysis patients studied above therapeutic blood levels of practolol of between 1.5 and 2.4 $\mu \mathrm{g} / \mathrm{ml}$ were obtained in only two of the nine patients given the $100 \mathrm{mg}$ dose, whereas such levels were obtained in all four patients given $200 \mathrm{mg}$. In all seven patients in whom it was estimated measurable amounts of between 0.3 and $1.9 \mu \mathrm{g} / \mathrm{ml}$ of practolol were detected in the blood at 72 hours. It would therefore appear that in patients being treated by twice-weekly maintenance haemodialysis, therapeutic blood levels of practolol can be maintained by giving $200 \mathrm{mg}$ by mouth at the beginning and end of each dialysis. Further work is necessary to substantiate these recommendations.

We would like to thank Dr. Brian Scales, of I.C.I., Ltd., for doing the practolol estimations. We are grateful to Dr. R. F. Jewkes and Miss B. E. Jones for doing the ${ }^{51} \mathrm{Cr}$-edetic acid clearances in some of the patients. We would also like to thank Sister Margaret Greatbatch and the Renal Unit staff for taking some of the blood samples.

\section{References}

Chantler, G., Garnett, E. S., Parsons, V., and Veall, N. (1969). Clinical

Science, 37, 169.
Fitzgerald, J. D., and Scales, B. (1968). Internationale Zeitschrift für klinische Pharmakologie, Therapie und Toxikologie, 1, 467.

MacDonald, A. G., and McNeill, R. S. (1968). British fournal of Anaesthesia $+0,508$.

Scales, B., and Cosgrove, M. B. (1970). Fournal of Pharmacology and Experi- 